\title{
Acute and Sub-chronic (28-day) intraperitoneal toxicity studies of the Methanol Root Extract of Securidaca longepedunculata Fresen (Polygalaceae) in Rats.
}

Haruna, $Y$.

Department of Medicinal Chemistry, Kebbi State University of Science and Technology, P.M.B. 1144, Aliero, Birnin Kebbi, Nigeria

\begin{abstract}
Despite the wide spread use of Securidaca longepedunculata in all parts of Africa, not much has been reported in the literature about its toxicity. The few reports available are in connection with its trypanocidal and insect toxicity where it is used as a stored grain preservative. In our investigation, it was discovered that intraperitoneal administration (i.p.) of limit dose of $2.83 \mathrm{mg} / \mathrm{kg}$ of the extract produced neither mortality nor acute signs of toxicity through out the 48 hours period of observation. In the sub-chronic toxicity study however, i.p. administration of the extract to rats produced dose dependent multiple organ toxicities in the kidneys and the liver. The rats showed signs of respiratory distress and muscle paralysis with a stretching of the hind limbs at the point of death. The extracts also significantly $(p<0.05)$ increased levels of AST and ALT which is diagnostic of hepatocellular damage; in view of the large scale human consumption of this plant even though, $L D_{50}$ is not a very reliable procedure in the determination of toxicity, however, patients usually combine herbal remedies with orthodox medication or with alcohol often with out the knowledge of the pharmacist or the physician. Considering the potential toxicity of $S$. longepedunculata, herbal practitioners should be educated on this, especially when the plant is recommended as part of the complex regimen in long term or short term management of chronic illnesses like hypertension and diabetes
\end{abstract}

\section{Council for Innovative Research}

Peer Review Research Publishing System

Journal: Journal of Advances in Biotechnology

\author{
Vol 2, No. 1 \\ editor@cirworld.com
}

www.cirworld.com, member.cirworld.com 


\section{Introduction}

Securidaca longepedunculata Fresen commonly known as violet tree (family polygalaceae) is a medium sized violet tree growing up to $6 \mathrm{~m}$ high. The flowers are in short bunches either pink or purple with sweet scent; they are produced early in summer. They are about $10 \mathrm{~mm}$ long, borne on a long peduncle. The violet tree is widely distributed in woodlands and arid savannas of tropical Africa, especially in the Northwest and Western part of Nigeria, in the Lampoon province of South Africa and Mozambique (Ojewole et al., 2000).

S. longepedunculata is the most popular of all the traditional medicinal plants in South Africa and is used in almost every conceivable ailment. Some vernacular names mean "king of medicines." In Northern Nigeria, it is called "Uwar magunguna" in Hausa literally translated "the mother of all drugs" a tribute to its very many numerous medicinal uses. It is reputed to have over one hundred medicinal uses (Dapar et al., 2007). The roots are poisonous, smell like wintergreen oil and are said to contain methyl salicylate. In some parts of West Africa they are used as arrow poison (Sapeika, 1944). The root and the bark are taken orally either powdered or as infusion for treating chest complaints, inflammation, abortion, ritual suicide, tuberculosis, infertility, venereal diseases and for constipation. Toothache can be relieved by chewing the roots. Infusions of the roots are used for washing tropical ulcers. In Limpopo, the Venda take roots for mental disorders and against children's illness during breast feeding, they also mix the powdered root with maize and sorghum beverages for men being sexually weak. In Zimbabwe, roots are given to people who are believed to be possessed by evil spirits. Powdered with water and salt they are used against snake bites and cough (Okoli et al., 2005; Olajide et al., 1998; Burkill, 1997; Neuwinger, 1996).

Despite the widespread use of $S$. longepedunculata in all parts of Africa, not much has been reported in the literature about its toxicity. The few reports available are in connection with its trypanocidal and insect toxicity where it is used as a stored grain preservative (Atawodi et al., 2003; Belmain et al., 2001). This study is therefore, aimed at investigating the acute and sub-chronic intra-peritoneal toxicity of the plant using the method of Lorke (1983).

\section{Material and Methods}

\section{Plant Material}

Roots were harvested from Securidaca longepedunculata plants collected from Zuru, in Kebbi State, North-Western Nigeria. The identity of the whole plant was confirmed by Mr U.S. Gallah, a taxonomist of the Herbarium Section of Department of Biological Sciences, Ahmadu Bello University Zaria, Nigeria; where a voucher specimen was deposited for future reference purposes and assigned a voucher number: 900149.

\section{Experimental Animals and Animal Husbandry}

Wister albino rats (19-23 g) of both sexes used for this study were purchased from the Animal House of the Department of Pharmacology and Therapeutics, Ahmadu Bello University, Zaria, Nigeria. Metallic and plastic cages constructed in Samaru, Zaria were used to house the animals. The animals were clinically examined and confirmed to be free of trypanosomes and plasmodia organisms. They were fed with standard rodent feed (Vital Feeds, Jos, Nigeria), and allowed access to tap water ad libitum. Individual animals were coded using picric acid

\section{Acute Toxicity Evaluation / Determination of Median Lethal Dose LD 50 (I.P. Route)}

Lorke's method (1983) was used for the LD 50 determination. Three animals were given widely differing doses for each of the test groups in phase one as; $10 \mathrm{mg} / \mathrm{kg}, 100 \mathrm{mg} / \mathrm{kg}, 1000 \mathrm{mg} / \mathrm{kg}$ respectively and a control group was given normal saline according to the weight of the animal. The animals were observed for toxic signs, and for further 24 hours, the number(s) of death(s) were recorded. The doses of second phase were selected based on the outcome of the first phase and observed further closely for yet another 24 hours too. The number(s) of death(s) or none in the groups were used to calculate the $\mathrm{LD}_{50}$ as

$L D_{50}=\sqrt{ }$ The Maximum Dose of Survival $X \sqrt{ }$ The Minimum Dose that caused death

\section{Sub-chronic Toxicity Studies on the Methanolic Extract}

The method described by Cha et al (1984) and adopted by Adeyemi (1988) was used for these studies. In these studies, rats were treated with methanol extract throughout. Ninety six male adult Wister rats were randomized into four groups each containing 24 rats and the following protocol was adopted. The rats were allowed to acclimatize to laboratory conditions for two weeks before the commencement of the study. Tween $80(0.3 \% \mathrm{v} / \mathrm{v})(0.2 \mathrm{ml} / \mathrm{kg})$ was used as vehicle for administration of $S$. longepedunculata.

Group 1: No infection, no treatment

Group 2: $0.14 \mathrm{mg} / \mathrm{kg}$ of Securidaca longepedunculata extract (SLE)

Group 3: $0.28 \mathrm{mg} / \mathrm{kg}$ of SLE

Group 4: $0.56 \mathrm{mg} / \mathrm{kg}$ of SLE.

Administration of the extract stopped after 60 days and the intention was to monitor surviving rats for 90 days. The rats were observed daily for clinical signs and symptoms of toxicity as well as weekly body weight changes. Six rats from each 
group were sacrificed at the end of weeks 2, 4 and 8; after which the experiment was terminated because the rats did not survive the 90 days.

The toxicity indices investigated include:

1. Haematological parameters

2. Liver function tests

3. Kidney function tests

4. Histopathological Analysis

For these purposes, two types of blood samples were collected:

-heparinized blood which was used for the determination of haematological parameters

-Serum was used in the determination of biochemical parameters such as: ALT, AST, ALP, Total albumin, bilirubin, creatinine, etc.

\section{Statistical Analysis}

Results were presented as mean \pm SEM. Tests of significance between means was done using Student $t-$ test and ANOVA as appropriate. Level of significance was considered to be $\mathrm{P}<0.05$.

Results

\section{Median Lethal Dose $\left(\mathrm{LD}_{50}\right)$ of Methanol Root Extract (Intra-peritoneal Route)}

Table 1a: Phase I of LD 50 (Intra-Peritoneal) of S. Iongepedunculata on rats

\begin{tabular}{llll}
\hline Group & $\begin{array}{l}\text { Dose } \\
(\mathrm{mg} / \mathrm{kg})\end{array}$ & $\begin{array}{l}\text { No. } \\
\text { Used }\end{array}$ & $\begin{array}{l}\text { No. of } \\
\text { Deaths }\end{array}$ \\
\hline $\begin{array}{l}\text { Normal } \\
\text { Saline }\end{array}$ & - & 3 & 3 \\
1 & 10 & 3 & 3 \\
2 & 100 & 3 & 3 \\
3 & 1,000 & 3 & 3 \\
\hline
\end{tabular}

Table 1b: Phase II of LD LD (Intra-Peritoneal) of S. longepedunculata on rats

\begin{tabular}{llll}
\hline Group & $\begin{array}{l}\text { Dose } \\
(\mathrm{mg} / \mathrm{kg})\end{array}$ & $\begin{array}{l}\text { No. } \\
\text { Used }\end{array}$ & $\begin{array}{l}\text { No. of } \\
\text { Deaths }\end{array}$ \\
\hline 1 & 2 & 1 & 0 \\
2 & 4 & 1 & 0 \\
3 & 8 & 1 & 1 \\
4 & 16 & 1 & 1 \\
\hline $\mathrm{LD}_{50}=2.8 \mathrm{mg} / \mathrm{kg}$ & &
\end{tabular}

Table 2: Mean body weight changes after 28 days

\begin{tabular}{lllll}
\hline $\begin{array}{l}\text { Dose } \\
(\mathrm{mg} / \mathrm{kg})\end{array}$ & $\mathrm{N}$ & Initial wt & Final wt & $\begin{array}{l}\text { Mean } \\
\text { weight } \\
\text { gain }\end{array}$ \\
\hline $\begin{array}{l}\text { Normal } \\
\text { saline }\end{array}$ & 24 & $\begin{array}{l}135.83 \pm \\
5.73\end{array}$ & $156.83 \pm 3.93$ & 2.10 \\
0.14 & 24 & $\begin{array}{l}132.00 \pm \\
5.60\end{array}$ & $137.50 \pm 3.50$ & $5.50^{*}$ \\
0.28 & 24 & $140.17 \pm 5.08$ & $144.33 \pm 2.06$ & 4.20 \\
0.56 & 24 & $146.50 \pm 9.70$ & $150.50 \pm 13.56$ & 4.00 \\
$*$ & & & \\
\hline Data are means \pm SEM; $\mathrm{n}=24 ;$ ANOVA; ${ }^{*} \mathrm{P}<0.05$ &
\end{tabular}


Table 3: Relative organ weight of rats for sub-chronic toxicity studies (28 days)

\begin{tabular}{lllllll}
\hline $\begin{array}{l}\text { Treatment/dose } \\
(\mathrm{mg} / \mathrm{kg})\end{array}$ & Heart & Lungs & Liver & Kidney & Spleen & Brain \\
\hline Normal saline & $0.0005 \pm 0.0004$ & $0.0013 \pm 0.010$ & $0.0053 \pm 0.0005$ & $0.0010 \pm 0.0006$ & $0.0006 \pm 0.001$ & $0.0013 \pm 0.0008$ \\
SLE 0.14 & $0.0005 \pm 0.0003$ & $0.0015 \pm 0.001$ & $0.0057 \pm 0.0003$ & $0.0011 \pm 0.0001$ & $0.0006 \pm 0.004$ & $0.0013 \pm 0.0008$ \\
SLE 0.28 & $0.0006 \pm 0.0005$ & $0.0014 \pm 0.010$ & $0.0052 \pm 0.0005$ & $0.0011 \pm 0.0004$ & $0.0008 \pm 0.002$ & $0.0013 \pm 0.0008$ \\
SLE 0.56 & $0.0005 \pm 0.0001$ & $0.0014 \pm 0.001$ & $0.0052 \pm 0.0005$ & $0.0011 \pm 0.0006$ & $0.0010 \pm 0.002$ & $0.0013 \pm 0.0008$ \\
\hline
\end{tabular}

${ }^{*}$ Data are means \pm SEM; $n=24 ;$ ANOVA; ${ }^{*} P<0.05$

Table 4: Biochemical parameters of rats after 28 days treatment with

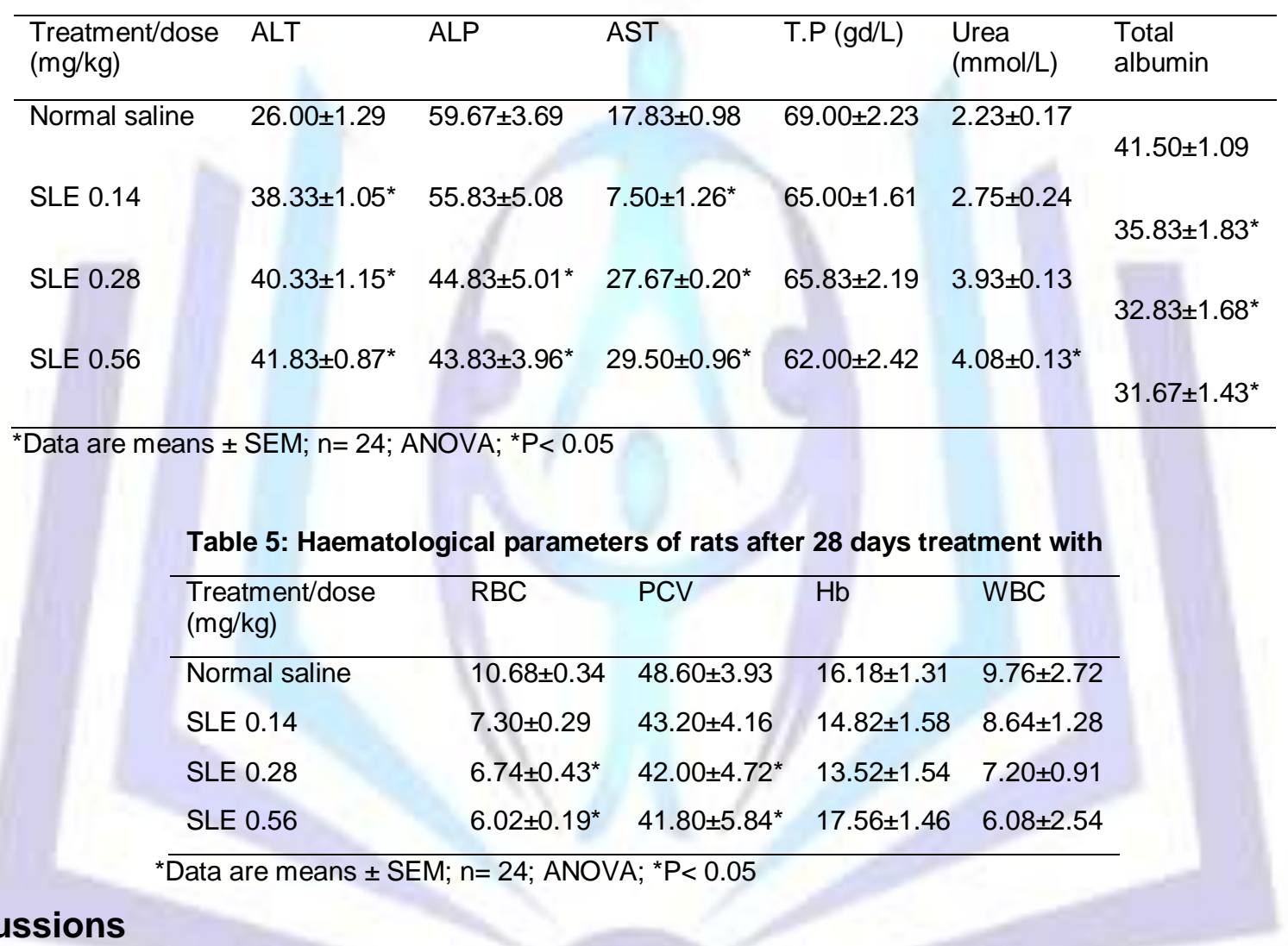

The result of the acute toxicity study indicated that the $\mathrm{LD}_{50}$ of methanol root extract of $\mathrm{S}$. longepedunculata in Wister albinorats is far less than the $5,000 \mathrm{mg} / \mathrm{kg}$ limit dose stipulated by Organization for Economic Cooperation and Development (OECD). The resultant death of all rats in phase one within 24 hours is suggestive of acute toxicity of the roots of this plant, (OECD, 2000).

\begin{abstract}
A 28 days study considered as sub-chronic is well accepted for eliciting any toxicity on long term by dosing repeatedly for 28 days with specific end points in mind. The extract appears to have no effect on organ weight and weekly body weight on mice except the lowest dose $(0.14 \mathrm{mg} / \mathrm{kg})$ where there was a significant $(p<0.05)$ decrease in body weight of the mice. The extract produced significant $(p<0.05)$ decrease in Red Blood Cells $(R B C)$ count at $0.28 \mathrm{mg} / \mathrm{kg}$ and $0.56 \mathrm{mg} / \mathrm{kg}$ and also in the Packed Cell Volume (PCV) at high and moderate doses. This might be due to inhibition of RBC production by the bone marrow or haemolysis of the blood cells by the active component of the extract.

The result of the biochemical studies indicates that the extract produced significant $(p<0.05)$ increase in ALT, AST, and Urea concentrations in the blood and decrease in ALT, which is an indication to injury if not damage to the liver and kidney respectively. S. longepedunculata been the most popular of all the traditional medicinal plants in South Africa and is used in almost every conceivable ailment. Some vernacular names mean "king of medicines." In Northern Nigeria, it is called "Uwar magunguna" in Hausa literally translated "the mother of all drugs" a tribute to its very many numerous medicinal uses. It is reputed to have over one hundred medicinal uses (Dapar et al., 2007). However; it is note worthy to be aware of its toxic potentials both acute and chronic.
\end{abstract}




\section{References:}

[1] Adeyemi, I.A. (1988) Ogi quality of sorghum flour dry-milled from fermented sorghum grains. Journal of food science 53: 641-642.

[2] Atawodi, S.E., Bulus, T., Ibrahim, S., Ameh, D.A., Nok, A.J., Mamman, M., Galadima, M. (2003). In vitro trypanocidal effect of methanol extract of Some Nigerian savannah plants. African Journal of Biotechnology, 2: 317-321.

[3] Belmain, S.R. and Steveson, P.C. (2001). Ethnobotanicals in Ghana. Reviving and modernizing age old farmer practice. Pesticide out look 12: 233-235.

[4] Burkil, H.M. (1997). The useful plants of West Tropical Africa, Royal Botanical Gardens families, kew, U.K,4 969. N.N., Gyang S.S., Tanko M.M. (2007). The histopathologic effects S. longepedunculata on heart, liver, kidney and lungs of rats. Afr. J. Biotech, 6:591-595.

[5] Cha, J., Elsebet, O. N., Jang H.O., Tage, H., John, B.P and Anne, B.Y (1988). Thiocyanate Stabilizes AMPA binding to the quisqualate receptor.European Journal of Pharmacology, 157, 197-203.

[6] Dapar, L.P.M., Aguiyi, C.J., Wannang, N.N., Gyang, S.S., and Tanko, M.N. (2007). The histopathologic effects of Securidaca longepedunculata on heart, liver, kidney and lungs of rats. African Journal of Biotechnology 6 (5):591595.

[7] Lorke, D. (1983). A new approach to practical acute toxicity. Achieves of toxicology, 54:275-287

[8] Neuwinger, H.D. (1996). African ethno-botany poisons and drugs, chemistry, pharmacology, toxicology. Pharmaceutical Biology. Chapman \& Hall, London. UK, Pp 743-753.

[9] Ojewole, J.A.O. Ilesanmi, O.R.S. and Olayiwola, G (2000). Pharmacology of Africa medicinal plants: Neuromuscular and cardiovascular properties of $S$. longepedunculata, Nig. J. Natl. Prod. Med. 4: 30-36.

[10] Okoli, C.O., Akah, P.A., Ezugworie, U (2005). Anti inflammatory activity of extract of root bark of S. longepedunculata fres (Polygalaceae). Afr. J. Trad. CAM 2 (3):54-63.

[11] Olajide, O.A., Awe, S.O., Makinde, A.M. (1998). Pharmacological Screening of the Root Extract of $S$. longepedunculata. Fitoterapia, 69 (3): 245-248.

[12] Organization for Economic Cooperation and Development (OECD), (2000). Guidelines,425, 2000.Guideline Document on Acute Oral Toxicity. Environmental Health and Safety Monograph Series on Testing and Assessment No. 24. Addendums to the Guidelines for the testing of chemicals: $104-425$.

[13] Sapeika N. (1944). Fatal Human Poisoning from plants in Southern Africa. Clin. Proceed 3:64-91. 